\title{
German/US health research agreement lacks substance
}

On February 24, US Health and Human Services Secretary, Donna Shalala and the German Science Minister, Jürgen Rüttgers, signed an agreement for the US and Germany to cooperate in health science and clinical research. The agreement calls for the two countries to work together "to resolve common health problems through research" and encourages collaborative efforts between scientists in both countries.

The contract is an extension of the "Agreement on Cooperation in the Field of Biomedical Research and Technology," which lapsed in 1991. Although the pact calls for coordinated scientific research programs, scientists can only apply for travel money-there are no funds for fellowships or for actual research, admits Bärbel Köster, of Germany's Federal Ministry of Education, Science, Research and Technology. The fact that money will be siphoned from existing national grants to support the program has led some to criticize the agreement as little more than a publicity stunt.

In addition, some researchers point out that collaborations have been in place for years, with no formal basis. "There are already many [US-German] collaborations that exist whose participants are completely unaware of this agreement," says Hermann-Josef Gertz, professor at the University Clinic for Psychiatry and Gerontopsychiatry in Leipzig and a participant of US-German Alzheimer's Disease workshops. Gertz agrees that it is research money that is really needed.

Thomas Stegmann from the Fulda Heart Center, thinks that few scientists in Germany are ever made aware of such programs. In fact, Stegmann's team was widely publicized in February to have "beaten" US scientists in a race to re-grow cardiovascular blood vessels, although Stegmann says he would have welcomed collaboration rather than competition. He believes he would gain from such an alliance, because despite presenting his vessel re-growth results at several meetings in Germany, "people only became interested after it was picked up by the American media."

However, German scientist Axel Fischer, says that his collaboration with researchers at Johns Hopkins Asthma and Allergy Center in Baltimore is a result of the old US/German cooperation agreement. "We have published 9 papers

together and two more are in the pipeline," says Fischer. Nevertheless, he is amazed that few groups take advantage of such programs: "Out of the 16 research groups that met through the original workshop I only know of three that actually collaborate."

But as for the promise of travel funds,

Fischer adds a note of caution-he was successful initially in receiving travel funds from the government, but those funds have now dried up. "The German body sees the money as a sort of kickstart. After that you have to look for the money yourself," complains Fischer.

Ellen Peerenboom, Cologne

\section{Rare science and medicine book auction}

Part of "the most comprehensive private library of science and medicine ever to come to auction" went under the ham. mer at Christie's of New York on March 18th. Two further auctions are sched. uled for later in the year. The collection belonged to San Francisco psychiatrist Haskell F. Norman, who died in 1996 and comprised 2,500 items in total, dating from the Renaissance to the $20^{\text {th }}$ Century.

tion was De humani corporis fabrica libri septem (1543), a study of human anatomy by Hapsburg imperial court physician, Andreas Vesalius, which was valued at $\$ 600,000$.

Part two of the auction in

IMAGE
UNAVAILABL
E FOR
COPYRIGHT
REASONS
June will sell off the works from the Age of Reason-the $17^{\text {th }}$ and $18^{\text {th }}$ centuries. This includes English physician William Harvey's famous treatise on the circulation of blood, Du motu cordis.

The final part of the collection-The Modern Age, $19^{\text {th }}$ and $20^{\text {th }}$ century books-will valued at \$2-3 million. On the block were pieces from the Middle Ages and the Renaissance, such as the c1500 work of Francisco Arceo, who produced the first version of the hippocratic oath in English. The "jewel" of the collec-

be auctioned in November and contains Marie Curie's doctoral dissertation on radioactivity, plus an 1859 copy of Darwin's On the Origin of Species.

\section{Karen Birmingham, New York}

\section{Pope calls for research into natural family planning}

Pope John Paul II has called for more scientific research into natural family planning and for a broader diffusion of knowledge of the scientific support for the Vatican-approved "rhythm method." The request came on the 30th anniversary of the papal document on the protection of human life and the unlawfulness of contraception and was directed specifically at the Center for Research on Natural Family Planning at the Catholic University "Sacro Cuore" in Rome. This is the first time that the Pope has been known to request more biomedical research in any area of health.

Supported by a special Sacro Cuore University fund, the Center is now planning to encourage research into the mucus signs of fertility by the World Health Organization-ovulation method-Billings (WOOMB international) group. The Center's director, Anna Cappella told Nature Medicine that "although the knowledge gained through many trials have given natural family planning centers and teachers a much greater understanding of the fertile and the infertile phases, many women still do not receive basic information on the cervical mucus pattern as a reliable method to achieve or to avoid pregnancy." Monsignor Elio Sgreccia, vice-president of the Pontifical Academy of Life, says that with the Papal seal, basic research on biochemical and biophysical markers of the fertile phase is expected to enjoy a worldwide renaissance.

Martina Ballmaier, Milan 